\title{
CoViD-19 Pnömonisinde Laktat Dehidrogenaz Düzeylerinin Önemi
}

\section{The Importance of Lactate Dehydrogenase Levels in COVID-19 Pneumonia}

\author{
Zeliha DEMIR GIDEN ${ }^{1}(\mathbb{D})$, Ramazan GIDEN ${ }^{2}$ (D) , Elif DEMiR ${ }^{3}$
}

${ }^{1}$ Viranşehir Devlet Hastanesi, Göğüs Hastalıkları Bölümü, Şanlıurfa, TÜRKiYE

${ }^{2}$ Harran Üniversitesi Tıp Fakültesi, Acil Tıp Anabilim Dalı, Şanlıurfa,TÜRKiYE

${ }^{3}$ Harran Üniversitesi, Viranşehir Sağlık Yüksekokulu, Viranşehir, Şanlıurfa, TÜRKiYE

Öz.

Amaç: Bu çalışmadaki amacımız, RT-PCR testi pozitif olan COVID-19 pömonisinde laktat dehidrogenaz seviyelerinin nasıl etkilendiğini tespit etmektir. Bu parametrenin RT-PCR testi pozitif hastalarda biyokimyasal parametre açısından değerini araştırmak, konuyla ilgili yeni görüşler ileri sürebilmektir.

Materyal ve Metod: Çalışmamıza hastaneye başvuran 18 yaş üstü RT-PCR testi pozitif olup servise yatışı olan 100 COViD-19 hasta dahil edildi. Hastaların verileri hastanenin sisteminden geriye dönük olarak toplandı. RT-PCR pozitif hastalar COVID-19 pnömonisi olan ve COViD-19 pnömonisi olmayan olarak iki gruba ayrıldı. Elde edilen sonuçlar SPSS 25 programında değerlendirildi.

Bulgular: RT-PCR testi pozitif olan 100 hastanın 39'unda COVID-19 pnömonisi yoktu, 61'inde COViD-19 pnömonisi vardı. COViD-19 pnömonisi olan hastaların laktat dehidrogenaz değeri, COViD-19 pnömonisi olma-

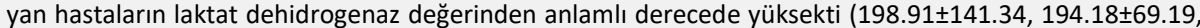
$\mathrm{p}=0.001$ ).

Sonuç: Yaptı̆̆ımız çalışmada COViD-19 pnömonisi olan hastalarda olmayanlara göre laktat dehidrogenaz değeri anlamlı derecede daha yüksek bulunmuştur. Bu yüzden çalışmamız hastaların ilk başvuru anındaki laktat dehidrogenaz değerlerinin bilgisayarlı tomografinin olmadığı sağlık kuruluşlarında ve bilgisayarlı tomografi çekiminin önerilmediği hasta gruplarında COViD-19 pnömonisini öngörmede kullanılmasının faydalı olabileceği fikrini akla getirmiș ve bilgisayarlı tomografi olan sağlık kurulușlarında ise COViD-19 hastalarında laktat dehidrogenaz değerinin yüksek çıkması bilgisayarlı tomografi taraması kararını vermede fikir verebileceğini düşündürmüştür.

Anahtar Kelimeler: COVID-19, Pnömoni, Laktat dehidrogenaz.

Abstract

Background: T Our aim in this study is to determine how lactate dehydrogenas levels are affected in RTPCR positive COVID-19 pneumonia. To investigate the value of this parameter in terms of biochemical parameters in RT-PCR positive patients and to propose new opinions on the subject.

Materials and Methods: One hundred COVID-19 patients admitted to the hospital with positive RT-PCR test and above the age of 18 were included in our study. The data of the patients were collected retrospectively from the hospital system. RT-PCR positive patients were divided into two groups as those with COVID19 pneumonia and those without COVID-19 pneumonia. The obtained results were evaluated in the SPSS 25 program.

Results: Of the 100 patients with positive RT-PCR test, 39 did not have COVID-19 pneumonia, 61 had COVID19 pneumonia. Lactate dehydrogenas levels of patients with COVID-19 pneumonia was significantly higher than lactate dehydrogenas levels of patients without COVID-19 pneumonia $(198.91 \pm 141.34,194.18 \pm$ $69.19, \mathrm{p}=0.001$ )

Conclusions: As a result of this study, the idea that the lactate dehydrogenas levels of the patients at the time of first admission may be useful in predicting COVID-19 pneumonia in healthcare institutions without computed tomography and in patient groups where computed tomography scan is not recommended, and in healthcare institutions with computed tomography, lactate dehydrogenas value is high in COVID-19 patients, computed tomography screening made us think that it can give an idea about the decision.

Keywords: COVID-19, Pneumonia, Lactate dehydrogenase. 


\section{Giriş}

COVID-19 salgını, Kasım 2019'dan beri dünya çapında sağlık sorunlarına neden oluyor. Bugüne kadar 200'den fazla ülke COVID-19 hastalığından etkilendi ve altı milyondan fazla doğrulanmış vaka 370.000 'den fazla ölüme yol açtı. SARSCoV-2 koronavirüs hastalığının (COVID-19) spektrumu, minimal semptomatik (ateş, öksürük, miyalji, balgam , baş ağrısı, hemoptizi, diyare, dispne) ile şiddetli pnömoni ve akut solunum sıkıntısı sendromu (ARDS) arasında değişir (1). COVID-19'un morbidite ve mortalitesi büyük ölçüde akut viral pnömoniye bağı ARDS'den kaynaklanmaktadır. Hastaların bir kısmında genellikle hastalığın ikinci haftasında nefes darlığı ve hipoksemi gözlenebilir. Şiddetli hastaların \%1020'sinde, hastalığın 8-14 gün aralığında, arteriyel parsiyel oksijen basıncı (PaO2) / solunan havadaki oksijen fraksiyonu (FiO2) <300 mmHg'dan olarak tanımlanan ARDS tablosu gelişip kardiyojenik olmayan akciğer ödemi nedeniyle mekanik ventilasyon gerekliliği doğabilir (2).

Laktat Dehidrogenaz (LDH), dokularda yaygın olarak eksprese edilen sitoplazmik bir enzimdir. Enzim, oksijen yetersiz olduğunda glikolizin son ürünü olan piruvatı laktata dönüştürür (3). LDH, iki ayrı kapalı alt birimden oluşur ve beş izozim ile sonuçlanır. Her izozim spesifik bir organda ifade edilir: kardiyomiyositlerde LDH 1, akciğer dokusunda LDH 3 ve hepatositlerde LDH 5 (4).

Doku hasarı, nekroz, hipoksi, hemoliz veya maligniteler gibi farklı durumlarda artmış LDH gözlenmiştir $(5,6)$. LDH, akut veya kronik doku hasarının genel bir göstergesidir ve inflamatuar bir belirteç olarak kabul edilir (7). Akut ve şiddetli akciğer hasarı sırasında LDH'nin arttığı tanımlanmıştır ve diğer interstisyel akciğer enfeksiyonlarında yüksek LDH değerleri bulunmuştur (8).

Bu çalışmadaki amacımız COVID-19 pnömonisi olan ve olmayan hastalarda LDH değerlerinin nasıl etkilendiğini tespit edip elde ettiğimiz sonuçlar doğrultusunda konuyla ilgili yeni görüşler ileri sürebilmektir.

\section{Materyal ve Metod}

Bu çalışma Helsinki Deklarasyonu ile ortaya konan tavsiyeler doğrultusunda yapılmıştır. Çalışma protokolü Etik Kurul tarafından onaylandı (Harran Üniversitesi Klinik Araştırmalar Etik Kurulu; Tarih:23/11/2020 No:Hru20.20.26). Çalışmamız retrospektif bir çalışmadır. Çalışmamıza hastaneye başvuran 18 yaş üstü RT-PCR (Real-Time Polymerase Chain Reaction) testi pozitif olan 100 COVID-19 hasta dahil edildi. Hastaların verileri hastanenin sisteminden geriye dönük olarak toplandı. Bu veriler, hastaların hastaneye ilk başvuru sırasındaki laboratuvar ve radyolojik bulgularını içermektedir. RT-PCR testi pozitif hastalar COVID-19 pnömonisi olan ve COVID-19 pnömonisi olmayan olarak iki gruba ayrıldı. Bu iki grubun LDH ve bazı laboratuvar bulguları değerlendirildi.

\section{İstatistiksel Analiz}

İstatistiksel analiz IBM SPSS 25.0 (SPSS for Windows, SPSS Inc., Chicago, IL, ABD) kullanılarak yapıldı. LDH seviyeleri normallik testi için Kolmogorow - Smirnov testi kullanıldı.
Gruplar normal dağılım göstermediği için Mann-Whitney U Testi kullanıldı. P <0.05 istatistiksel olarak anlamlı kabul edildi.

\section{Bulgular}

COViD-19 olan 100 hastanın 46'sı erkek 54'ü kadın hastaydı. Bu 100 hastanın 39'unda COViD-19 pnömonisi yok (toraks bilgisayarlı tomografi (BT) negatif) iken, 61'inde COViD-19 pnömonisi mevcuttu toraks bilgisayarlı tomografi (BT) pozitif). Pnömonisi olmayan hastaların 19'u erkek 20'si kadın ve yaş ortalamaları 38.90 \pm 14.09 idi. Pnömonisi olan hastaların ise $28^{\prime} i$ erkek 33'ü kadın olup yaş ortalamaları 41.70 \pm 15.76 idi (Tablo 1 ).

Tablo 1. BT negatif ve BT pozitif COViD-19 hastalarının yaş ortalaması ve cinsiyet dağılımı.

\begin{tabular}{lcc}
\hline Gruplar & Cinsiyet (Erkek/Kadın) & Yaş (yıl) \\
\hline BT Negatif & $19 / 20$ & $38.90 \pm 14.09$ \\
BT Pozitif & $28 / 33$ & $41.70 \pm 15.76$ \\
\hline
\end{tabular}

Hastaların LDH değerleri incelendiğinde pnömonisi olmayan hastaların LDH değeri ortalamasını 194.18ะ69.19; pnömonisi olan hastaların LDH değerlerini ise 198.91 \pm 141.34 olarak bulduk. Pnömonisi olan hastalarda LDH değerlerini pnömonisi olmayan hastalara göre daha yüksek bulmakla birlikte istatistiksel olarak anlamlı saptadık $(p=0,001)$. Hasta grubunda ölçülen LDH seviyeleri Tablo 2'de gösterilmiştir.

Tablo 2. BT negatif ve BT pozitif COVID-19 hastalarının LDH değerlerinin karşılaştırılması.

\begin{tabular}{lcc}
\hline Gruplar & LDH (U/L) & P değeri \\
\hline BT Negatif & $194.18 \pm 69.19$ & \multirow{2}{*}{0.001} \\
BT Pozitif & $198.91 \pm 141.34$ & \\
\hline
\end{tabular}

$\mathrm{Bu}$ çalışmada hastaların kreatinin, AST (aspartat aminotransferaz), ALT (alanin aminotransferaz), WBC (white blood cell, akyuvarlar) ve CRP (C-reaktif protein) değerleri de incelenmiştir. Her iki hasta grubunda da bu değerlerin ortalamalarına bakılmıştır. Her iki grupta da kreatinin, AST, ALT ve WBC değerlerinin ortalamalarının birbirine benzer olduğu görülüp bu değerlerin normal aralıkta olduğu saptanmıştır. CRP değerinde ise her iki grubun ortalaması normal aralıktan yüksek bulunmuş olup pnömonisi olan hastalardaki CRP değerleri pnömonisi olmayanlara göre daha yüksek bulunmuştur (Tablo 3).

Tablo 3. BT negatif ve BT pozitif COVID-19 hastalarının laboratuvar bulguları.

\begin{tabular}{lcc}
\hline & BT Pozitif & BT Negatif \\
\hline CRP $(\mathrm{mg} / \mathrm{L})$ & $37.76 \pm 64$ & $9.05 \pm 22$ \\
AST $(\mathrm{U} / \mathrm{L})$ & $32.74 \pm 18.23$ & $28.97 \pm 19.38$ \\
ALT $(\mathrm{U} / \mathrm{L})$ & $29.26 \pm 18.25$ & $35.28 \pm 31.58$ \\
WBC $\left(10^{\wedge} 3 / \mathrm{uL}\right)$ & $6.78 \pm 2.82$ & $6.38 \pm 2.46$ \\
Kreatinin & $1.09 \pm 1.05$ & $0.88 \pm 0.27$ \\
(mg/dL) & & \\
\hline
\end{tabular}




\section{Tartışma}

COVID-19 enfeksiyonunun en yaygın semptomları kuru öksürük ve ateş olup bu semptomlar ARDS ve uç organ yetmezliğine ilerleyerek interstisyel pnömoniye dönüşebilir (1). Acil Servisler çok sayıda kritik hasta ile karşı karşıyadır ve klinik senaryonun her zaman akciğer hasarının ciddiyetine karşılık gelmediği de yaygın bir durumdur. Periferik oksijen saturasyonu düşük ve şiddetli akciğer hasarı olan hastalar bile bazen dispneden şikâyet etmeyebilirler $(9,10)$. LDH, laktatın piruvata dönüştürülmesiyle enerji üretiminde rol oynayan bir enzimdir ve kalp, karaciğer, akciğerler, kaslar, böbrekler ve kan hücrelerinde en yüksek seviyelerde olup hemen hemen tüm vücut hücrelerinde bulunur. LDH, akut veya kronik doku hasarının genel bir göstergesidir ve inflamatuar bir belirteç olarak kabul edilir (7).

Serum LDH'nin virüsteki faydası ilk kez 1988'de Zaman ve arkadaşları tarafından araştırılmıştır. Serum LDH seviyesinin, insan immün yetmezlik virüsü ile enfekte hastalarda P.jirovecii pnömonisinin bir belirteci olarak yararlı olduğu bulunmuştur (11). Ede ve diğerleri ise viral üst solunum yolu enfeksiyonu sırasında nazofaringeal sekresyonlardaki LDH seviyeleri ile ölçülen nazofaringeal hücre hasarının ciddiyetinin akut otitis media komplikasyonu ile ilişkili olduğunu bildirmişlerdir (12). Şimdiye kadar LDH'nin enerji üretiminde rol oynayan ve vücuttaki hemen hemen tüm hücrelerde bulunan bir enzim olduğunu biliyorduk. Kandaki LDH konsantrasyonunu ölçen testler, karaciğer hastalığı ve interstisyel akciğer hastalığı dahil olmak üzere çok çeşitli bozukluklarla ilişkili doku hasarını izlemek için yaygın olarak kullanılır. LDH artışı doku/hücre tahribatını yansıtır ve doku/hücre hasarının ortak bir işareti olarak kabul edilir ve SARS-CoV-2'nin neden olduğu pnömoni gibi viral enfeksiyon veya akciğer hasarını düşündürür. Serum LDH'nin idiyopatik pulmoner fibrozun aktivitesi ve ciddiyeti için önemli bir biyobelirteç olarak tanımlandığını da biliyoruz (13).

Tao Chen ve ark.'nın yaptığı retrospektif çalışmaya alınan hastaların 113'ünde mortalite gelişmiş olup diğer hastalar iyileşmiştir. Mortal seyreden hasta grubunda LDH anlamlı olarak daha yüksek bulunmuştur (14). Başka bir çalışmada ise hastalar hafif seyreden (görüntüleme bulgusu ve pnömonisi olmayan) ve ciddi seyreden olarak iki gruba ayrılmış ve LDH seviyesi ciddi seyreden grupta anlamlı olarak daha yüksek görülmüştür (15). Chaomin Wu ve ark.'nın COViD19 tanısı almış 201 hastada yaptığı çalışmada ARDS gelişen grupta gelişmeyen gruba göre LDH anlamlı derecede daha yüksek bulunmuştur. Aynı zamanda ARDS gelişmiş grupta mortal seyreden hastalarda da LDH değeri daha yüksek olarak tespit edilmiştir (16). Başka bir çalışmada akciğer grafisi ve/veya toraks BT'si normal hastalar ile anormal olan hastalar karşılaştırılmış ve LDH değeri anormal olan grupta anlamlı olarak daha yüksek bulunmuştur (17).

Biz ise yaptığımız çalışmada RT-PCR pozitif hastaları toraks $\mathrm{BT}^{\prime}$ de pnömonisi olan ve olmayan olarak iki gruba ayırıp LDH değerlerini inceledik. Toraks BT'de pnömonisi olan hastalarda LDH değerlerini, pnömonisi olmayan hastalara göre daha yüksek tespit edip istatistiksel olarak da anlamlı bulduk.

Yüksek akut solunum yetmezliği riski taşıyan COVID-19 hastalarının erken tespiti ve yeterli tedavisi, ARDS ve uç organ hasarından kaçınmak için çok önemlidir. Pan ve ark. Tarafından bildirildiği gibi, toraks BT COVID-19 pnömonisinde akciğer tutulumunun tanı ve ciddiyetinin değerlendirilmesinde çok önemli bir role sahiptir (18). Günümüzde BT, pulmoner hasarı tahmin etmek için kullanılmaktadır (19) ve BT bulguları, olumsuz sonuçları tahmin etmek için yararlı olabilir (20). Fakat ne yazık ki BT tüm Acil Servislerde mevcut değildir. Ayrıca T.C. Sağlık Bakanlığı rehberinde de yer aldığı gibi 20 yaş altı genç kadınlara, çocuklara ve gebelere BT ön planda önerilmemektedir (21). Bu yüzden COViD-19 hastalarında akciğer tutulumunu öngörebilecek parametrelere ihtiyaç vardır. Yaptığımız bu çalışma hastaların ilk başvuru anındaki LDH değerlerinin COVID-19 hastalığında akciğer tutulumunu öngörebileceğini düşündürmüştür.

COVID-19'un mortalitesi büyük ölçüde akut viral pnömoniye bağlı ARDS'den kaynaklanmaktadır. Bu yüzden COVID19 hastalarında akciğer tutulumunun varlığının gösterilmesi erken tedavi açısından çok önemlidir. Yaptığımız çalışmada LDH değerini COVID-19 pnömonisi olan hastalarda, olmayanlara göre anlamlı derecede daha yüksek bulduk. Bu yüzden hastaların ilk başvuru anındaki LDH değerlerinin BT'nin olmadığı sağlık kuruluşlarında ve BT çekiminin önerilmediği hasta gruplarında COVID-19 pnömonisini öngörmede kullanılması faydalı olabilir. Bununla birlikte BT'si olan sağlık kuruluşlarında ise COViD-19 hastalarında LDH değerinin yüksek çıkması, BT taraması kararını vermede fikir verebileceğini düşündürmüştür. Yalnız bu fikri destekleyecek daha geniş çalışmalara ihtiyaç vardır.

Etik onam: Harran Üniversitesi Klinik Araştırmalar Etik Kurulu; Tarih:23/11/2020 No:Hru20.20.26.

\section{Yazar Katkıları:}

Konsept: Z.D.G., R.G

Literatür Tarama: Z.D.G., R.G

Tasarım: Z.D.G., E.D.

Veri toplama: Z.D.G., E.D.

Analiz ve yorum: Z.D.G., R.G

Makale yazımı: Z.D.G., E.D.

Eleştirel incelenmesi: Z.D.G., R.G

Çıkar Çatışması: Yok

Finansal Destek: Yok

\section{Kaynaklar}

1. Huang C, Wang Y, Li X, Ren L, Zhao J, Hu Y. Clinical features of patients infected with 2019 novel coronavirus in Wuhan, China. Lancet. 2020;395:497-506. doi: 10.1016/S01406736(20)30183-5.

2. Zhou M, Zhang X, Qu J. Coronavirus disease 2019 (COVID19): a clinical update. Frontiers of medicine. 2020:1-10.

3. Feron $\mathrm{O}$. Pyruvate into lactate and back: from the Warburg effect to symbiotic energy fuel exchange in cancer cells. Radiotherapy and oncology: journal of the European Society for 
Therapeutic Radiology and Oncology. 2009;92(3):329-33.

4. Glick JH Jr. Serum lactate dehydrogenase isoenzyme and total lactate dehydrogenase values in health and disease, and clinical evaluation of these tests by means of discriminant analysis. American journal of clinical pathology. 1969;52(3):320-8.

5. Karlsson $M$, Wiberg-Itzel $E$, Chakkarapani $E$, Blennow $M$, Winbladh B, Thoresen $M$. Lactate dehydrogenase predicts hypoxic ischaemic encephalopathy in newborn infants: a preliminary study. Acta paediatrica (Oslo, Norway: 1992) 2010;99(8):1139-44.

6. Kato GJ, McGowan V, Machado RF, Little JA, Taylor Jt, Morris $\mathrm{CR}$. et al. Lactate dehydrogenase as a biomarker of hemolysis-associated nitric oxide resistance, priapism, leg ulceration, pulmonary hypertension, and death in patients with sickle cell disease. Blood. 2006;107(6):2279-85.

7. Sepulveda J. Challenges in Routine Clinical Chemistry Analysis: Proteins and Enzymes. Editor(s): A. Dasgupta, J. L. Sepulveda, Chapter 9, Accurate Results in the Clinical Laboratory, Elsevier, 2013;131-148.

8. McFadden RG, Oliphant LD. Serum lactate dehydrogenase in interstitial lung disease (letter) Chest 1991; 100 (4): 1182. doi: 10.1378 / Chest.100.4.1182-b.

9. Poggiali E, Ramos PM, Bastoni D, Vercelli A, Magnacavallo A. Abdominal pain: a real challenge in novel COVID-19 infection, Eur. J. Case Rep. Int. Med. 7(4) (2020) 001632. Published 2020 Mar 26. doi:10.12890/2020_001632.

10. Poggiali E, Dacrema A, Bastoni D. Can lung US help critical care clinicians in the early diagnosis of novel coronavirus (COVID-19) pneumonia? Radiology. 2020;295(3):E6. doi: 10.1148/radiol.2020200847.

11. Zaman MK, White DA. Serum lactate dehydrogenase levels and Pneumocystis carinii pneumonia. Diagnostic and prognostic significance. Am. Rev. Respir. Dis. 1988;137:796-800.

12. Ede LC, O'Brien J, Chonmaitree T, Han Y, Patel AJ. Lactate dehydrogenase as a marker of nasopharyngeal inflammatory injury during viral upper respiratory infection: implications for acute otitis media. Pediatr Res. 2013;73:349-54.

13. Kishaba $T$, Tamaki H, Shimaoka Y, Fukuyama H, Yamashiro S. Staging of acute exacerbation in patients with idiopathic pulmonary fibrosis. Lung. 2014;192:141-149. doi: 10.1007/s00408-013-9530-0.

14. Chen T, Wu DI, Chen H, Yan W, Yang D, Chen G, et al. Clinical characteristics of 113 deceased patients with coronavirus disease. 2019: retrospective study. BMJ 2020;368:1091. https://doi. org/10.1136/bmj.m1091.

15. Wan $S$, Xiang $Y$, Fang $W$, Zheng $Y$, Li B, Hu Y, et al. Clinical features and treatment of COVID-19 patients in northeast Chongqing. J Med Virol 2020;92:797-806. https://doi. org/10.1002/jmv.25783.

16. Wu C, Chen X, Cai Y, Xia J, Zhou X, Xu S, et al. Risk factors associated with acute respiratory distress syndrome and death in patients with coronavirus disease 2019 pneumonia in Wuhan, China. JAMA Intern Med 2020;e200994. https://doi.org/10.1001/jamainternmed.2020.0994.

17. Zhang $X$, Cai H, Hu J, Lian J, Gu J, Zhang S, et al. Epidemiological, clinical characteristics of cases of SARS-CoV-2 infection with abnormal imaging findings. Int J Infect Dis 2020;94:8187.https://doi.org/10.1016/j.ijid.2020.03.040.

18. Pan $F$, Ye $T$, Sun P. Time course of lung changes at chest $C T$ during recovery from coronavirus disease 2019 (COVID-
19) Radiology. 2020;295(3):715-721. doi: 10.1148/radiol.2020200370.

19. Chung M, Bernheim A, Mei X. CT imaging features of 2019 novel coronavirus (2019-nCoV) Radiology. 2020;295(1):202207. doi: $10.1148 /$ radiol.2020200230.

20. Colombi D, Bodini FC, Petrini M, Maffi G, Morelli N, Gianluce $M$, et al. Well-aerated Lung on Admitting Chest CT to Predict Adverse Outcome in COVID-19 Pneumonia. Radiology, 2020;201433. doi:10.1148/radiol.2020201433.

21. T.C. Sağıık Bakanlığı, Covid-19 (SARS-CoV-2 Enfeksiyonu) Rehberi Bilim Kurulu Çalışması Ankara; 2020 [updated 14 Nisan 2020; cited 2020]. Available from: https://covid19bilgi. saglik.gov.tr/depo/rehberler/COVID-19_Rehberi.pdf. 